\title{
O DIREITO NO ESTADO DA ARTE: ANTÍGONA, O MERCADOR DE VENEZA E O PROCESSO NA RECONSTITUIÇÃO DA HISTORIOGRAFIA FORENSE
}

\section{THE LAW AT THE STATE-OF-THE-ART: ANTIGONE, THE MERCHANT OF VENICE AND THE TRIAL AT THE RECONSTITUTION OF FORENSIC HISTORIOGRAPHY}

\author{
${ }^{1}$ Arthur Magalhães Costa \\ ${ }^{2}$ Lucas Mikael Martins Costa Barreto Campello
}

\section{RESUMO}

Sabe-se que a Arte sempre acompanhou a trajetória do ser humano, tendo figurado como expressão de sua alma desde os primórdios da humanidade até o mais recente período. Sendo então o Direito, constructo formatado a partir da regulação da convivência social, percebe-se na literatura, boa oportunidade de analisar as especificidades e entrelinhas que marcaram o Ordenamento Jurídico ao longo dos tempos. O presente trabalho voltar-se-á a captar o ideal de justiça em contraste com as características e complexidades próprias do Direito Natural Clássico a partir de Sófocles, o Direito renascentista por Shakespeare e o Direito Contemporâneo pelas linhas de Kafka.

Palavras-chave: Palavras-chave: direito e literatura, Historiografia forense, Justiça

\begin{abstract}
It is known that Art has accompanied the human being in its path, having appeared as its soul expression since the beginnings of humankind until the most recent times. Hence the Law, a formatted construct from the regulation of socialization, it is possible to realize from literature a good opportunity to analyze the specificities which have marked the Legal System through times. The present paper will verse towards the capturing of the justice ideal, contrasting with the very own characteristics and complexities of Classic Natural Law from Sophocles, Renaissance Law from Shakespeare and Contemporary Law from the lines of Kafka.
\end{abstract}

Keywords: Keywords: law and literature, Forensic historiography, Justice

\footnotetext{
${ }^{1}$ Mestrando em Direito pela Faculdade Damas da Instrução Cristã - FADIC, Pernambuco (Brasil). E-mail: arthur.mcosta@hotmail.com

${ }^{2}$ Mestrando em Direito pela Faculdade Damas da Instrução Cristã - FADIC, Pernambuco (Brasil).

E-mail: lbcampello@hotmail.com
} 


\section{1) Notas introdutórias: o Direito na literatura}

Como pura expressão de arte, a literatura clássica pôde abarcar a partir das obras

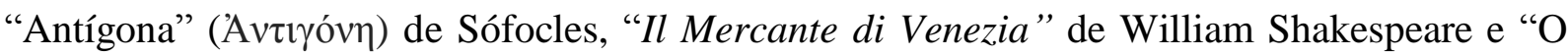
Processo" de Franz Kafka, completas demonstrações do período histórico e todas as implicações aos quais a sociedade estava submetida, levando em consideração o Direito, a Política, as crenças religiosas e os ideais de justiça, verdade e razão. Por apresentarem contextos históricos distintos e marcarem períodos específicos da humanidade, tais obras são, portanto, de inestimável valia, por apontarem todo um nicho de conhecimento que deve ser explorado, justificando estudos mais aprofundados.

Estudar o veio artístico que compõe a natureza humana é nesse sentido compreender o homem e o seu ambiente. Não por outra razão justifica-se ainda que ciente da superficialidade da exploração que se pretenderá engendrar no presente texto, percebe-se vital a reaproximação do Direito e da Arte, como ensina Carnelutti ${ }^{1}$, “estudar o direito e a arte significa atacar a partir dos dois lados diversos o mesmo problema. [...] A arte, como o direito, serve para ordenar o mundo". (CARNELUTTI, 2005, p.10). Por arte, tomando seu sentido platônico, sendo assim técnico, sabe-se, representa-se "todo conjunto de regras capazes de dirigir uma atividade humana qualquer" (ABBAGNANO, 2012, p.93). Por outro lado, sendo vislumbrada sob os moldes kantianos, mais precisamente à divisão entre arte mecânica e arte estética, poder-se-á observá-la sob a finalidade da procura pelo prazer, sendo assim, espécie de representação cujo fim está em si mesmo e que tem por finalidade a busca do prazer desinteressado. (KANT, 1790 apud ABBAGNANO, 2012). Em outras palavras, queria dizer Immanuel Kant, dentro das artes estéticas, o que reputou por bem chamar de "Belas Artes" $"$. No torpor da arte, já reputava Friedrich Nietzsche que assim como o filósofo se portava, perante a realidade da existência, assim se comportaria o homem, artisticamente impressionável, ao contemplar atentamente, haja vista que seria por estas imagens que ele interpretaria a vida. (NIETZSCHE, 2006).

\footnotetext{
${ }^{1}$ Tomando em consideração do ofício do artista, ensina Francesco Carnelutti no auge de sua maturidade que: "O que fazem estes poucos homens não é nada de diverso do que fazem o poeta e o pintor: a arte, em suma. E não devemos crer que um e outro descreva tão só o que viu e ouviu, fisicamente, quer dizer, em outras palavras, o que existe no passado; o que não descreve senão o passado é um fotógrafo ou um cronista, não um poeta ou um pintor. O artista, na verdade, conta o que seus olhos e não os olhos da multidão alcançaram vendo o fundo da realidade, onde unem-se o passado e o futuro. Arte, portanto, também dos homens que buscam representar as leis do espírito com as leis da natureza. Como exemplo, o aconselharia pensar nos juristas romanos, que se não cultivaram a ciência do direito na sua significação mais moderna e própria” (CARNELUTTI, 2005, p.30-1).

${ }^{2}$ Não há dúvida de que, dentre muitas definições, as características e pontuações observadas pelo conceito kantiano atingem melhor o que se buscará reputar como arte no presente texto.
} 
De mais a mais, nada obsta, seja também encarado o Direito como Arte. Sim, o movimento Law and Literature $^{3}$, nascido nos Estados Unidos da América em meados dos anos 80, tinha por objetivo encontrar na literatura pontos de apoio ao Direito, tudo de modo a permitir sua melhor compreensão. Nesse sentido, poderia a Literatura conduzir o Direito com fito de permitir o aprofundamento de seus valores e de suas decisões. (SCHWARTZ; MACEDO, 2006). É dizer, tal movimento, procurou abordar suas perspectivas em uma divisão tripla: “o Direito na Literatura ${ }^{4}$, o Direito como Literatura e o Direito da Literatura. Dessa tricotomia, aceita também na Europa, exsurge o formato de como se estudar o Direito com base na Literatura" (SCHWARTZ; MACEDO, 2006, p.1020). Mister que se diga, o aspecto que melhor remonta a relação entre Direito e Literatura se apresenta no fato de que os grandes clássicos da literatura universal, assim como as obras que serão estudadas "guardam testemunhos da forma como se dava a prática jurídica no contexto sociocultural de uma determinada época, o que é um aspecto relevante na compreensão das expressões legítimas do Direito no passado histórico" (SILVA; RIBEIRO, 2014, p.2).

Em suma, não há dúvidas que a Arte permite ao observador, tal como fotografias que relembram os períodos passados, o regresso ao modelo jurídico que coexistia com os povos de outrora, tal como um retorno ao espaço-tempo, a possibilidade de análise das repercussões, das especificidades e das entrelinhas que a pura e isolada prescrição, letra fria da lei, não seria capaz de engendrar. Nesse sentido, o que se buscará no presente trabalho, sem a pretensão de esgotar o tema, compreenderá uma abordagem das presentes obras de arte tomadas tanto em separado ao fixar os pontos de divergência e especificidades culturais, assim como uma análise em conjunto ao abarcar os principais pontos de convergência, dirigindo nesse sentido verdadeira intersecção entre escalas temporais, sem perder de vista a apreciação das características que acompanham e adornam tais marcos da literatura e do cinema internacionais. Desta maneira, situados os recortes históricos, buscar-se-á identificar as peculiaridades do ideal de justiça levando em consideração os aspectos consuetudinários que muito foram salientados no curso de tais expressões artísticas.

\footnotetext{
${ }^{3}$ Segundo os pesquisadores Germano Schwartz e Elaine Macedo: "O Law and Literature Movement procurou abordar suas perspectivas em uma divisão tripla: o" Direito na Literatura, o Direito como Literatura e o Direito da Literatura. Dessa tricotomia, aceita também na Europa, exsurge o formato de como se estudar o Direito com base na Literatura" (SCHWARTZ; MACEDO, 2006, p.1020).

${ }^{4}$ Vale colacionar: "O Direito na Literatura é o ramo da disciplina Direito e Literatura que estuda as formas sob as quais o Direito é representado na Literatura. Cada forma de tratamento poderá interessar a um determinado campo jurídico" (SCHWARTZ; MACEDO, 2006, p.1021).
} 


\section{2) O amor de Antígona: A solidez dos costumes em face dos decretos imperiais}

Obra formatada pelo dramaturgo ${ }^{5}$ Sófocles, a partir da mitologia clássica, apresenta em meio à Cidade-Estado de Tebas, Grécia Antiga, a história de Antígona ${ }^{6}$, filha do Rei Édipo, ao qual tendo acompanhado seu Pai diante do exílio, ao regressar, assiste a morte de seus dois irmãos Polinice e Etéocles por conta do interesse pela coroa. A partir daí, assume o trono Creontes, ao qual em primeiro decreto imperial, proíbe que qualquer do povo preste rito fúnebre ao corpo de Polinice. Justifica-se ante o fato de já ter Polinice tentado dominar Tebas anteriormente, sem sucesso. Irresignada, Antígona descumpre o decreto e ao ser descoberta é mandada pelo Rei para o exílio dentro de uma caverna escura, onde posteriormente retira a própria vida. Profundamente entristecido, comete também suicídio o filho do Rei Creontes, Hêmon, noivo de Antígona. Uma vez falecido seu filho, Eurídice, mulher do Rei Creontes também vem a suicidar-se, fazendo com que o Rei Creonte demasiadamente abalado e arrependido deixe o trono e passe a vagar sem rumo pela Grécia, deixando Tebas. (SÓFOCLES, 2005).

Trata-se de uma tragédia ${ }^{7}$, formatada sob os moldes clássicos da cultura grega ${ }^{8}$, agregando consigo, vasto valor histórico que se demonstra a partir dos costumes sociais ao qual

\footnotetext{
${ }^{5} \mathrm{O}$ pesquisador Marcelo Alves, aprofundando a cultura grega, esclarecendo a origem do teatro, pôde constatar que: “ Dentre os diversos legados da cultura grega, o teatro ocupa um lugar bastante singular como manifestação artística, a um só tempo, altamente sofisticada e de grande apelo popular. Nascido do culto a Dionisio, o deus do vinho, o teatro irá se originar em meio a festas religiosas rurais de crescente popularidade na Grécia. Essas festividades celebravam a eterna renovação da vida, os mistérios que a envolvem e a integração do homem com o seu fluxo incessante e poderoso. Dioniso, símbolo da força vital, convida seus devotos a se integrarem à natureza, a romperem as regras e convenções sociais que os tornam indivíduos, seres isolados, separados uns dos outros e da grande unidade original que a natureza representa. [...] Os devotos de Dioniso disfarçavam-se em Sátiros, representavam-nos por meio do uso de máscaras, e entoavam cânticos corais em louvor ao seu deus. Teria sido esta, segundo uma forte corrente de interpretação, a origem do teatro ou, para ser mais preciso, do gênero trágico" (ALVES, 2007, p.23-4).
}

\footnotetext{
${ }^{6}$ Vale constatar que no tocante à Antígona, “desgraças irreparáveis e grandes provações marcam o seu destino. A primeira desgraça prende-se ao seu nascimento, pois ela é fruto de incesto de Édipo com a própria mãe. A segunda consiste na pesada missão de guiar o pai, cego e banido de Tebas, por toda a vida, em sua peregrinação, amparandoo até a morte, em Colono" (BARROS, s/a, s/p).
}

${ }^{7} \mathrm{Na}$ compreensão de Marcelo Alves, em explicação à origem da palavra tragédia, o próprio vocábulo guardaria a marca de sua origem: “seria a junção de 'trágos' (bode) e 'oidé' (canto), significando assim 'o canto do bode' ou, ainda, 'o canto em louvor ao bode' - uma vez que o próprio Dioniso, em uma de suas transmutações, também aparece como bode" (ALVES, 2007, p.24).

${ }^{8}$ Em análise à religiosidade dos gregos antigos, Friedrich Nietzsche demonstrava que "o grego conhecia e sentia os sustos e horrores da existência: mas, a fim de poder viver, os cobria com as brilhantes figuras de sonho dos Olímpicos. Aquela enorme desconfiança para com as forças titânicas da natureza; aquela Moira reinante sobre todos os conhecimentos, sem compaixão, [...] foi suplantada continuamente pelos gregos por aquele mundo médio dos olímpicos; pelo menos coberta e afastada dos olhares. A fim de poder viver foram os gregos obrigados a criar esses deuses da maior necessidade. [...] Como poderia ter suportado a existência aquele povo tão sensível, tão 
convivia a humanidade. Tendo em vista o fato de que a pratica judicial descansava integralmente na estimada autoridade dos costumes e na tradição oral, a importância primordial do período primitivo e suas ideias acerca do direito apoiavam-se na ideia ao qual os homens viam o Direito. Nesse sentido, ao pretender descobrir o fundamento da elevada posição do homem, a lei e a justiça formatavam o centro da cultura humana. (JAEGER, 1982). "Em Antígona, Sófocles representa esse conflito em toda a sua complexidade de carne e espírito, abordando, a um só tempo, os dramas existenciais, políticos, religiosos, jurídicos e éticos que tal tensão produz numa sociedade politicamente organizada" (ALVES, 2007, p.20). Chama a atenção de $\operatorname{logo}$ as pormenoridades que sob os olhos do homem contemporâneo não faria qualquer sentido, todavia, tendo em vista as especificidades consuetudinárias como a importância dos ritos fúnebres para uma existência tranquila do espírito e sob pena de não o fazendo, o amargor de um post mortem sobrecarregado de sofrimento e dor. Tão significativa é tal circunstância que leva um mulher apaixonada à abandonar sua própria vida ao escolher desrespeitar um decreto imperial. Interessante constatar que em rico estudo da cultura grecoromana, Fustel de Coulanges trouxe com clareza que os mortos eram considerados entes sagrados. Ademais, a morte não era tida como simples decomposição do ser, senão, simples mudança de vida. (COULANGES, 2005). A partir daí era clara a importância de uma sepultura. Pode-se dizer que para a alma primitiva se fixar na morada subterrânea voltada para a segunda vida, era necessário que o corpo fosse coberto de terra. Nesse sentido, a alma que não tivesse o seu túmulo, certamente não teria morada. Assim sendo, viveria errante ${ }^{9}$, deixando de ter o repouso que acreditava um dia possuir após a vida que havia levado. (COULANGES, 2005). Justificava-se, pois, a preocupação de Antígona com a segunda vida do seu irmão Polinice. Não à toa, tal obra é consagrada como exemplo clássico de conflito normativo, haja vista abarcar ordenamentos religiosos em contraponto ao direito criado pelo príncipe. (BARROS, s/a). Por outro lado, marcante é a figura da posição do Pater Familias a partir do confronto entre Hémon e o Rei Creontes. Após o julgamento de Antígona, seu noivo Hémon desejoso de mudar a

\footnotetext{
desejoso, tão inclinado aos sofrimentos, se ela não lhe fosse apontada como rodeada de uma glória superior, em seus deuses? [...] Os deuses justificam a vida humana vivendo-a eles mesmos". (NIETZSCHE, 2006, p.49-50).

${ }^{9}$ Ipsis litteris, "a alma ficaria condenada a errar eternamente, sob a forma de larva ou de fantasma, sem jamais parar, sem nunca receber as oferendas e os alimentos de que tanto precisava. Desgraçada, cedo essa alma se tornaria amaldiçoada. Atormentaria então os vivos, enviando-lhes doenças, devastando-lhes as searas, atormentando-os com aparições apavorantes, para deste modo os advertir de que tanto o seu corpo quanto ela própria queriam sepultura. Toda a antiguidade se convence de que, sem sepultura, a alma vive desgraçada e que só pelo seu enterramento adquiria a felicidade para todo o sempre. Não era pelo aparato da dor que se realizava a cerimônia fúnebre, mas peara repouso e felicidade do morto" (COULANGES, 2005, p.13).
} 
decisão paternal, questiona seu pai, ouvindo como resposta verdadeira lição ${ }^{10}$ que atestara a relevância da instituição paterna para a constituição da família na época assinalada. Conforme o pesquisador Fustel de Coulanges, o pai seria o primeiro junto ao lar, seu pontífice, intermediador de todos os cultos, senhor da vida de sua família, seja dos filhos, seja de sua mulher. (COULANGES, 2005).

Outro aspecto que deve ser levado em consideração diante da análise da tragédia em comento, sem dúvida passa pelo problema político enfrentado pelo Rei Creontes diante da desobediência de sua sobrinha Antígona. Como lidar com tal problema? Dos escritos de Sófocles, desejando o Rei ser obedecido em todas as circunstâncias, ainda que diante inúmeros conselhos em contrário, seja do seu filho, sejam de seus súditos, conselheiros e até do respeitado sábio, temia abrir um precedente para a futura perda de eficácia de suas demais decisões e decretos. ${ }^{11}$ E assim, desprezando os votos em contrário tomou a decisão de trancafiar a transgressora em uma caverna escura, fato que desdobrou-se em tantos outros terríveis o bastante para fazê-lo abandonar o trono de Tebas. A obra de Sófocles demonstra assim a importância da eficácia na projeção do Direito Grego. O legítimo temor de um Rei diante da desobediência popular frente aos seus mandamentos. Ao zelar pela eficácia, Creontes assim o faz utilizando-se do poder coercitivo, ao tempo em que degladia-se com a justiça de seu ato. Eis aqui a principal problemática que envolve a tragédia de Sófocles. Confronta-se a eficácia dos decretos com a justiça. Sabendo todos os conselheiros do Rei ser tal pena capital excessiva e afastada do que se entende por decisão justa, ao mesmo tempo imprudente e desnecessária, mantem-se Creonte firme ao respeito por sua autoridade de Rei. Como vontade soberana, viase aquilo que o Rei decidira, ainda que contra o interesse popular. Creontes portanto, decidido à apoiar Etéocles, tomando com isso contraposição aos atos de Polinice, ordenara que um dos irmãos teria sob seu túmulo todos os ritos fúnebres e demais imolações para sua graça, em total

\footnotetext{
${ }^{10} \mathrm{Na}$ fala de Creontes: "Eis a prudente regra, meu filho, que é preciso guardar no coração! Tudo nos deve provir da vontade paterna. A única razão pela qual os homens desejam que nasçam e cresçam em sua casa novos rebentos, é a certeza de que estes, mais tarde, ataquem o seu inimigo, e honrem o seu amigo, tão bem como o pai o faria. Quem quer que tenha filhos inúteis, não terá feito outra coisa senão angariar para si motivos de desgosto, e para seus inimigos uma fonte de risos" (SÓFOCLES, 2005, p.44).

${ }^{11}$ Conforme a argumentação do Rei Creontes, “Visto que eu a prendi, quando, ostensivamente, transgredia a uma de minhas ordens, e foi a única pessoa, em toda a cidade, a proceder assim! Eu não quererei passar por mentiroso e fraco diante do povo, e ordenarei sua morte. Se eu tolero a rebeldia daqueles que pertencem à minha estirpe, com mais forte razão transgredirei com a de estranhos! Quem é rigoroso na decisão de seus casos domésticos, será também justo no governo do Estado. [...] O homem que a cidade escolheu para chefe deve ser obedecido em tudo, quer seus atos pareçam justos, quer não. Quem assim obedece, estou certo, saberá tão bem executar as ordens que lhe forem dadas, como comandar, por sua vez; e será, na guerra, um aliado valoroso e fiel. Não há calamidade pior do que a rebeldia; ela é que arruína os povos, perturba as famílias, e causa a derrota dos aliados em campanha" (SÓFOCLES, 2005, p.45).
} 
oposição ao que se observaria com os restos mortais de Polinice. Ocorre que, os cuidados fúnebres por se tratarem de condutas fundadas na religião à época, guardavam total relação com o Direito, haja vista este confundir-se muitas vezes com os desideratos religiosos e estar sem qualquer sombra de dúvidas profundamente arraigado à tais condutas. Não por outra razão, os conselheiros discutiam com o Rei a possibilidade de perdão, haja vista que ao tomar para si o dever de cuidar de seus mortos, Antígona não agia de outro modo senão tomando a conduta mais apropriada e que guardava maior relação com os ditames religiosos. Era pois ao mesmo tempo dever de Antígona zelar pelos seus antepassados e contemporâneos falecidos, sob pena de graves maldições à sua família e negócios ${ }^{12}$. Não por outra razão o mito de Antígona, recriado por Sófocles, clareia a importância e a supremacia dos costumes religiosos sobre os decretos e desejos imperiais. Acaba-se, pois, por predizer um destino trágico ao Rei, tendo-o avisado por meio de um sábio chamado Tirésias, ao qual todas os prenúncios ${ }^{13}$, tornaram realidade. Ao guiar-se imprudentemente contra um ato religioso, Creontes amaldiçoa a si mesmo, pondo fim ao seu curtíssimo reinado. Ora, "se a justiça possuía seu lugar definitivo e dominante na ordem divina das coisas" (JAEGER, 1982, p.22), dado não ser o Direito uma criação humana, estava presente na natureza das coisas e do mundo, daí a denominação de natural. (BRANDÃO, 2012). O jusnaturalismo, pautava-se desta maneira muito mais à serviço dos ditames religiosos do que no cumprimento de decretos imperiais. Os costumes encontravam-se acima dos desideratos reais, representando nesse sentido inconteste importância para o manejo da Cidade. Essa sem dúvida se mostra como a mensagem principal ao qual Sófocles conduzindo o famoso mito, procurou relatar.

\footnotetext{
${ }^{12}$ Durante o julgamento, Antígona ressalva ao Rei Creontes que tinha por dever engendrar os ritos fúnebres para com Polinice. "Antígone: - Seja como for, Hades exige que a ambos se apliquem os mesmos ritos!" (SÓFOCLES, 2005, p.35). Em outro momento, "Antigone - Quanto a mim, dediquei minha alma ao culto dos mortos" (SÓFOCLES, 2005, p.39). Mais adiante, em conversa com O Corifeu, diz-se: - Ação piedosa é prestar culto aos mortos; mas, quem exerce o poder, não quer consentir em ser desobedecido. Teu caráter voluntarioso causou tua perda" (SÓFOCLES, 2005, p.56).

${ }^{13}$ Tomando o conselho do mago Tirésias, "Esta desgraça iminente é causada por tuas resoluções... os altares da cidade, as aras consagradas aos deuses, estão cheios de pedaços da carne do infeliz filho de Édipo... Eis porque os deuses repelem nossas orações, e rejeitam nossos holocaustos; não se ergue a chama sobre as vítimas; nem as aves soltam cantos de bom augúrio, visto que estão saciadas com o sangue humano... Pensa nisto meu filho! O erro é comum entre os homens: mas quando aquele que é sensato comete uma falta, é feliz quando pode reparar o mal que praticou, e não permanece renitente. A teimosia produz a imprudência. Cede diante da majestade da morte: não profanes um cadáver ! [...] Sabe, pois, que não verás o sol surgir no horizonte muitas vezes, sem que pagues, com a morte de um de teus descendentes, o resgate de outra morte, pois acabas de pôr sob a terra uma criatura que vivia na superfície, e a quem indignamente encerraste, viva, num túmulo; por outro lado, tu reténs, longe dos deuses subterrâneos, um cadáver, privado de honras fúnebres e de sepultura! Tu não tens o direito de o fazer; nem tu, nem qualquer divindade celeste! É uma inaudita violência, a que praticaste! [...] Vais sofrer os mesmos males que estás causando! Contra ti já se erguem as cidades irritadas, cujos altares estão poluídos pelas exalações dos cadáveres que não receberam sepultura a não ser das aves e dos cães" (SÓFOCLES, 2005, p.63-6).
} 
Em Antígona, Sófocles adentra na ideia de que o Direito Natural, imerso na mitologia e nos costumes, seria valido e superior ao direito de Tebas, criando imediatamente uma resistência ao limite do soberano de poder. Nesse sentido, insurge o entendimento de que em se tratando de uma norma sagrada nem mesmo o soberano poderia contrariá-la. Percebe-se nesse interim, uma ambivalência entre o direito positivo e o natural, uma distinção clara entre ambos, entre o direito transcendente sagrado e o posto, a lei terrena do soberano. Nesse diapasão, o direito natural atravessou os séculos, tendo influenciado efetivamente as ideias jurídicas ao longo da História.

\section{3) Il Mercante di Venezia: o poder dos contratos}

Urge agora aclarar outra literatura de grande monta. Situada historicamente em meio ao contexto do Renascimento, a obra do autor ${ }^{14}$ inglês William Shakespeare ${ }^{15}$, escrita entre 1596 e 1598 apresenta a história de um jovem italiano de nome Bassânio que desejoso de impressionar uma rica herdeira de nome Pórcia, pleiteia ao seu fiel amigo Antônio, mercador de Veneza, que o conceda uma boa quantia em dinheiro. Por outro lado, em não possuindo tais valores em mãos, porém tudo indicando que o conseguiria com o retorno dos navios de sua posse, abarrotado de mercadorias valiosas, o mercador toma empréstimos para com um judeu de nome Shylock, que entrega os valores mediante um contrato assinado ao qual possui como cláusula penal em face de inadimplemento a entrega de uma libra da carne de Antônio. (SHAKESPEARE, 2002). A situação se agrava a partir do naufrágio dos navios, tornando Antônio totalmente vulnerável aos desejos do judeu, ao qual diante do habitual destempero dos cristãos italianos para com sua doutrina e religião, aproveitara a situação para vingar-se da

\footnotetext{
${ }^{14}$ Importante aclarar as menções realizadas pelos pesquisadores Cristian Kiefer da Silva e Fernando José Armando Ribeiro. Diga-se: "Dentro dos modernos estudos de Direito e Literatura ressaltam aqueles que se atém sobre a obra de William Shakespeare (1564-1616), dramaturgo inglês e mais renomado expoente do chamado "teatro elisabetano", a maior expressão cultural da renascença inglesa e uma das mais aclamadas. Suas peças, que englobam tragédias e comédias, são extremamente representativas da realidade histórica da época, retratando por vezes situações onde se percebe uma crítica aos valores culturais vigentes ou sátiras de situações e personalidades, não só da Inglaterra elisabetana, mas de toda a Europa renascentista no auge do século XVI"(SILVA; RIBEIRO, 2014, p.01-02).

${ }^{15}$ Conforme o prefácio de Helena Barbas, tradutora da obra The Merchant of Venice, para a versão em Português, interessante se observa que "O Mercador de Veneza está incluído na secção das comédias shakespearianas porque mistura o riso com o drama (como todas as outras, aliás); entendem ainda os estudiosos que, sendo uma peça dos primeiros anos de produção estará ainda muito colada às estratégias do teatro medieval, da commedia dell'arte, das miracle plays, porém se lida com atenção, revela-se de uma modernidade inesperada. [...] Existem várias edições da peça. Foi publicada em 1598, no quarto de 1600 e depois no póstumo de 1623" (SHAKESPEARE, $2002, \mathrm{~s} / \mathrm{p})$.
} 
sociedade. Nesse sentido, totalmente assegurado dos mecanismos jurídicos, o judeu busca o foro veneziano para pleitear a execução do contrato assinalado, sendo impedido pelas hábeis argumentações ${ }^{16}$ do jovem juiz que em verdade, tratava-se de um disfarce ao qual encontravase Pórcia para defender o amado amigo de Bassânio. (SHAKESPEARE, 2002).

Situada uma rápida síntese da história perpassada ao longo da presente obra, convém abarcar com maior detença o contexto social ao qual encontrava-se tal "comédia trágica”. Sabese que na área de Direito e Literatura, certamente a maior contribuição de Shakespeare foi sem qualquer margem de erro, reputar no âmbito da sociedade inglesa da época, a força que o aparelho jurídico possuía e demonstrava dentro de uma sociedade hierarquicamente estabilizada, sem prejuízo da possibilidade de analisar os correntes efeitos reguladores. (SILVA; RIBEIRO, 2014). Nesse sentido, tendo em vista que o período renascentista foi compreendido por volta do fim do século XIV e início do século XVII, de fato configurou-se como o rompimento do medievo, e a perda de força de grande parte dos dogmas católicos que influenciavam em níveis de plenitude o comportamento social. Pode-se dizer que tal período foi avistado como a porta de entrada da modernidade a partir da retomada do pensamento clássico, considerado dantes pagão e doravante necessário para a melhor compreensão da humanidade. É na renascença que se dá início à revolução do pensar científico, tangível, palpável, em prejuízo à metafísica esmagadora dos cânones. A par disso, ante a ascensão da burguesia e suas práticas comerciais, restava-se perceptível um apego à contratualidade como característica principal do fenômeno jurídico naquele recorte cronológico ${ }^{17}$. Conforme Tércio Sampaio Ferraz Jr, acerca da teoria jurídica na era moderna, a partir do renascimento, o direito passava a perder progressivamente seu caráter sagrado, ao passo que implantaria a correspondente tecnicização do saber jurídico e a equivalente perda do seu caráter ético, que a Era Medieval cultuara e conservara. A era chamada de Direito Racional, iria de $1600^{18}$ a 1800 ,

\footnotetext{
16 "Pórcia: - Espera um pouco. Há algo mais. Esta fiança não te dá direito a uma gota de sangue, as tuas palavras especificam meio-quilo de carne. Toma então a tua fiança, toma o meio-quilo de carne, mas, ao cortá-lo, se derramares uma gota de sangue cristão, as tuas terras e bens, pelas leis de Veneza, ser-te-ão confiscadas para o Estado de Veneza. [...] Portanto, prepara-te para cortar a carne. Não derrames sangue, nem cortes menos nem mais. Mas apenas meio-quilo: se cortares mais ou menos do que um meio-quilo exacto, seja tanto que o faça leve ou pesado na substância, ou a divisão da parte proporcional de um vigésimo de um pobre grama, não, se a balança virar na estimativa nem que seja por um cabelo, tu morres e todos os teus bens são confiscados" (SHAKESPEARE, 2002, p.69-70).

17 "Shylock: - Vinde comigo a um notário, e assinai-me uma fiança única. E, por tal brincadeira, se não me pagardes em tal dia, em tal lugar, tal soma ou somas como estipulado nas condições, deixai que o penhor seja exatamente meio quilo da vossa carne branca, a ser cortado e tomado da parte do vosso corpo que mais me agradar" (SHAKESPEARE, 2002, p.16).

${ }^{18}$ Tendo sido a obra finalizada por volta de 1596, já era perfeitamente perceptível o fenômeno do Direito Racional nas linhas shakespearianas.
} 
onde auctoritas e ratio dominavam o pensamento jurídico medieval cujo caráter dogmático assinalava um respeito pelos textos a serem interpretados. (FERRAZ JR., 2009). A cláusula civilista do "pacta sunt servanda" abarcava a prevalência do Direito Privado, larga influência do Direito Romano, ressurgido, marcava-se a importância dos tratos e o prestígio que acompanhavam as cidades que respeitassem tais relações entre indivíduos. A relação contratual, portanto, entre os personagens Shylock e Antônio, demarcam ainda que em total contrassenso ao interesse coletivo da massa que grita pela piedade por parte do judeu usurário, a importância da segurança jurídica na manutenção e preservação do Direito na cidade de Veneza. É dizer, instado a garantir a execução do contrato sob pena de instalação de grave crise e prejuízo aos negócios da Cidade ${ }^{19}$, o Duque de Veneza, magistrado que preside o embate entre os pactuantes, não encontra outra saída senão também apelar pelo perdão ${ }^{20}$, haja vista que não seria possível em primeiro plano afastar o cumprimento dos duros termos clausulados ${ }^{21}$. Como se disse, tais circunstâncias marcaram a forte inclinação do direito veneziano àquela época, ao qual desde que confiado em pacto assinado e reconhecido, era dever do Estado executá-lo, indiferentemente ao apelo social. Aliás, as próprias especificidades do contrato, após aprofundada investigação por Pórcia, travestida de jurista, demonstraram que não houvesse Shylock pactuado com exatidão os meio quilos de carne, mas um valor aproximado, sem prejuízo das demais decorrências de tal extração, teria sido possível sua execução sem quaisquer impedimentos. Tais informações levam a crer que o conceito de justiça naquele caso não estava arraigado à vida humana ou a dignidade, mas tão somente à execução de um pacto que pressupõe a perfeita vontade das partes. Natural que o marco histórico ao qual o presente conto tematiza, apresentava em meio à queda do absolutismo e da ascensão da burguesia, a compreensão da liberdade contratual como ponto nevrálgico do ordenamento jurídico. Natural que fosse o poder distribuído das mãos do monarca para a vontade coletiva, onde selariam nos

\footnotetext{
19 "Shylock: - O meio-quilo de carne, que exijo dele, é comprado a alto preço: é meu e quero-o. Se mo negarem, pior para a vossa lei! Não há força nos decretos de Veneza. Estou a pedir julgamento. Respondei-me: tê-lo-ei? [...] Anseio pela lei, a pena e o pagamento da minha fiança (SHAKESPEARE, 2002, p.62-3).

${ }^{20}$ Oferecendo uma oportunidade de acordo, o Duque ou Doge de Veneza, na função de magistrado, procura ante as circunstâncias do duro termo clausulado, a possibilidade de perdão. Ipsis litteris: "Duque de Veneza - Shylock, o mundo pensa, e eu também penso assim, que só te comportas dessa maneira por malícia até ao último momento do Acto. Acha-se que então irás mostrar misericórdia e remorso, mais estranhos do que tua estranha e aparente crueldade. [...] Não apenas renunciará ao pagamento da fiança, mas tocado de delicadeza e amor humanos, perdoarás a metade do capital. [...] Todos esperamos uma resposta gentil, Judeu" (SHAKESPEARE, 2002, p.691).

21 "Pórcia: - Não há poder em Veneza que possa alterar um decreto estabelecido: Será registrado como um precedente, e muitos erros seguindo o mesmo exemplo acorrerão Estado adentro. (SHAKESPEARE, 2002, p.66).
} 
pactos sejam comerciais, sejam sucessórios, sejam a partir de qualquer ato civil, o poder da vontade como viga mestra do Direito. Assim sendo, não havendo qualquer vício volitivo na realização daquele pacto, nada obstante o uso de parte do corpo do pactuante como garantia ante o descumprimento do trato, poderia ser tal contrato perfeitamente executável. Em suma, no Mercador de Veneza, tomando como recorte o estudo do Direito na Literatura, pode-se afirmar que fez a presente obra elevado grau de conotação acerca do justo/injusto, alcançando também deste modo, o uso simbólico do Direito a partir das representações que uma sociedade exterioriza no tocante à suas normas jurídicas. (SCHWARTZ; MACEDO, 2006).

Por outro lado, também os aspectos religiosos apresentam absoluta influência sob a temática da peça abalizada. O judaísmo, entre suas características peculiares não eram bem acomodados no cenário italiano renascentista. É clara a hostilização ${ }^{22}$ voltada para os semitas que vivendo em um ambiente apartado de Veneza, pouquíssimo prestígio possuíam, ainda que acumuladores de massiva riqueza. Dentre as múltiplas interpretações possíveis da conduta do judeu Shylock, pode-se pensar que tratava-se de um sedento por vingança, um avarento irascível, entre outras características que marcam quem meio-quilo ou uma libra de carne humana insere como cláusula penal em um pacto qualquer. Porém, é possível compreender que por tratar-se de um juramento, não cabia aquele judeu a possibilidade de perdão, ou misericórdia, sob pena de pecado, ou qualquer outra moléstia à alma, no plano metafísico de existência. A ideia de vingança, por sua vez, insurge ante o desprestígio do judeu diante da comunidade Cristã, com toda uma sorte de condutas voltadas para rebaixá-lo, como moradia afastada, vedações à determinadas atividades, et caterva. Pode-se somar tal sentimento de fúria por parte dos demais cristãos, a partir da fuga de sua única filha, Jéssica, que abandonando Shylock, parte com seu amado Lourenço para uma vida deleitosa, em total contrassenso aos duros costumes judaicos. Tais fatores portanto, somados ao juramento realizado, fizeram do rico judeu, verdadeiro vilão na empolgante história narrada por Shakespeare.

No entanto, a genialidade do autor remete à uma das mais famosas passagens da literatura shakespeariana, no momento em que Shylock, procurando erradicar o preconceito que sofria, traça comparações aos cristãos ${ }^{23}$, demonstrando que era tão homem quanto aqueles que

\footnotetext{
22 Conforme Schwartz, se configura outrossim foco essencial da presença do Direito na Literatura: "O tratamento que o Direito e o Estado dispensam às minorias ou grupos oprimidos, como mulheres, imigrantes, raças, religião, entre outros" (SCHWARTZ; MACEDO, 2006, p.1021).

${ }^{23}$ Em diálogo com Salarino, o judeu Shylock demonstra sua irresignação diante do tratamento dado pelos cristãos ante o fato de não pertencer ao mesmo convívio religioso. Ipsis litteris: "Shylock - Ele desgraçou-me, e fez-me perder meio milhão, riu-se das minhas perdas, troçou dos meus ganhos, zombou da minha nação, destroçou as minhas barganhas, arrefeceu-me os amigos, aqueceu-me inimigos. Qual o motivo? Porque sou Judeu. Será que um Judeu não tem olhos? Um Judeu não tem mãos, órgãos, dimensões, sentidos, afectos, paixões? Não é alimentado
} 
o diminuíam, igualando-se na dor, na suscetibilidade a doenças, na necessidade de alimentação, et caterva. Tal momento desafia a origem do preconceito, que como se observa, na própria etimologia da palavra, aponta uma ideia de prejulgamento, "uma antecipação não problematizada de um conceito" (ABBAGNANO, 2012, p.924). Trata-se de circunstância que pode ser positiva se tomada sob a égide de expectativas e pressuposições em sede científica que antecedem quaisquer pesquisas, mas que assumem por sua vez valor negativo quando insertas no comportamento social, seguidas de violência e exclusão.

Outro ponto que se deve levar em consideração, fazendo um aporte a partir da instituição do casamento, tendo em vista a manifestação da vontade do pai de Pórcia antes do seu falecimento, havia deixado um enigma ao qual o pretendente que conseguisse desvendar, teria a mão da rica e bela herdeira. Vê-se claramente a presença do poder familiar paternalista e praticamente supremo em contrapartida à total submissão da figura feminina. Notória é a insatisfação e ansiedade de Pórcia. Trata-se de jogo ao qual, diante de três caixas, sendo uma delas de ouro, outra de prata e uma de chumbo, dentro de uma delas encontra-se uma foto da bela Pórcia, ao qual quem encontrá-la a tomará como esposa. Para tornar a escolha mais difícil, diante de cada caixa encontravam-se frases que atrairiam ou repeliriam o interessado. (SHAKESPEARE, 2002). Para tanto, até a vitória de Bassânio, pela graça e alegria de Pórcia, passou esta por situações de desgosto ao ver por pouco seu futuro ser desenhado diante de figuras de caráter excêntrico e de costumes totalmente diferentes aos quais estava ambientada. Pode-se afirmar que Shakespeare ao tempo em que apresentava peculiaridades daquela sociedade em tom cômico, em verdade, tomava tais situações para tecer duras críticas aos modelos familiares.

Como se pôde observar, "O Mercador de Veneza", explora elementos culturais de toda a sorte, abarcando particularidades de cunho religioso, jurídico, social, cultural e familiar. Talvez por abarcar tamanha riqueza, tal obra continue entre outras de sua autoria servindo de espetáculo tanto em películas como em inúmeros palcos teatrais, despertando alongados aplausos.

\footnotetext{
com a mesma comida, ferido com as mesmas armas, sujeito às mesmas doenças, curado pelos mesmos meios, aquecido e arrefecido pelo Inverso e Verão, como um cristão? Se nos picarem, não sangramos? Se nos fazem cócegas, não rimos? Se nos envenenam não morremos? E se nos fizerem al, não nos deveremos vingar? Se somos como vocês no resto, também somos parecidos nisso. Se um Judeu fizer mal a um Cristão, qual é a sua humildade? A vingança. Se um cristão fizer mal a um Judeu, qual deveria ser a sua tolerância de acordo com o exemplo cristão? Ora, a vingança. A vilania que me ensinam, eu a porei em prática" (SHAKESPEARE, 2002, p.41-2).
} 


\section{4) Do torpor do processo: O Direito como pesadelo infindável}

Em perfeita conexão com a complexidade do período moderno, o escritor tcheco, nascido em Praga, em 3 de julho de 1883, Franz Kafka ${ }^{24}$, em obra escrita por volta de 1920, "Der Prozess", narra a história de um homem conhecido como Sr. K, que em um dia incomum, como se estivesse em um pesadelo, toma ciência de uma acusação não especificada. Detido ${ }^{25}$ por agentes supostamente estatais, busca de todas as maneiras encontrar uma solução, situação que apenas se agrava e se aprofunda, atingindo complexidades cada vez maiores. Durante a luta para descobrir qual a razão de ser do processo-crime, sente o grande peso da burocracia judiciária, a partir da difícil comunicação com agentes policiais, dificuldade de acesso ao advogado e distanciamento profundo dos magistrados. Desta forma, envolto em grave crise, o Sr. K, termina sendo condenado à morte, sem passar por um julgamento, nem tampouco saber o crime ao qual respondia.

Trata-se de obra profundamente crítica do Direito Positivo, da alta complexidade do acesso à justiça, a partir do abismo linguístico que separa os juristas dos leigos, da sobrecarga processual que se acumula nas instâncias forenses, na presunção de culpabilidade que cerca a atuação do Estado e da enorme burocracia que circunda o fenômeno do processo. Em rápido comento, pode-se dizer que a alta complexidade do acesso à justiça se apresenta a partir da dificuldade em obtenção de informações, audiências, que assim como o Sr. K, vivera o cidadão do séc. XX e que guardadas as devidas proporções ainda acompanham grande parte dos litigantes do século XXI, também. A par disso, o abismo linguístico, por sua vez, envolvendo o conhecimento das leis e regras que cobrem o Ordenamento Jurídico, marca a forte característica da justiça forjada nas codificações, contendo assim natureza estritamente legal, afastada de sensos e juízos morais. Desta forma, conforme apresentada na obra em comento, a distância entre aqueles que dominam o conhecimento jurídico, sendo assim os operadores do

\footnotetext{
${ }^{24}$ Diocleciano Torrieri Guimarães em comento à obra estudada, aborda que "Franz Kafka reconstrói com angústia o mundo íntimo e transforma os seus personagens [...] em criaturas humanas, plasmadas pelo mistério, separadas em mundos de ideias próprias que se chocam e se interpenetram. [...] Percebe-se claramente que Franz Kafka instituiu, dentro dos quadros da literatura, novos métodos de pesquisa, enquadrando o homem não mais dentro dos limites angustos de uma história pré-fabricada, porém já liberto de todas as peias do romantismo e não visto de um ângulo determinado, mas um todo complexo, atuante e participante” (KAFKA, 2011, p.32-3).

${ }^{25}$ Da vistosa complexidade ao qual o Sr. K. apresenta-se envolvido é chegado o momento em que descobre qual a finalidade daqueles estranhos em seu quarto: “- Desejo falar com a senhora Grubach - exclamou K, e fazendo um movimento como para livrar-se dos dois homens que, contudo, se encontravam a uma considerável distância dele, intentou deixar a sala. -Não - retrucou o homem que estava junto à janela. [...] Você não pode sair; está detido. -É o que parece - disse K. - e por quê? - perguntou depois. - Não nos cabe explicar isso. Volte para seu quarto e espere ali. O inquérito está em curso, de modo que se inteirará de tudo em seu devido tempo. [...]" (KAFKA, 2011, p.41).
} 
Direito e o cidadão comum, é ressaltada nos brevíssimos e sempre enigmáticos esclarecimentos entre o advogado contratado e o Sr. K, assim como, perante os demais clientes que famintos por informações, chegam a residir no escritório advocatício, à espera de uma consulta ${ }^{26}$. De igual maneira, o acesso aos juízes e informações processuais são severamente tolhidos, fazendo com que se acumulem litigantes nos corredores do Fórum, adentro dos portões da justiça, numa espera incessante. Em um cenário infernal, pilhas e mais pilhas de processos se acumulam por toda parte, como casos que possuem um começo, porém jamais contemplarão um fim. O Poder Judiciário, nesse contexto, repita-se, é retratado de maneira nebulosa, distante, impessoal. Uma verdadeira engrenagem que funciona em desfavor dos jurisdicionados, ao qual, quando se vê embaraçado nos tentáculos da justiça, adentra em um eterno limbo, onde definitivamente, nada possui solução. O Tribunal descrito por Kafka mais lembra um grande teatro público, onde as pessoas riem, aplaudem e assistem aos julgamentos como qualquer outro espetáculo artístico.

Em suma, formalismo excessivo e burocracia confundem-se com justiça nesse pesadelo vivido pelo Sr. K. Pode-se levar em consideração além disso, a figura da presunção de culpabilidade como princípio marcante da atuação do Estado no mundo de Kafka, onde toda a comunicação é realizada para o fomento da condenação. A luta do Sr. K pela comprovação de inocência diante da vultuosa peleja que o engendra, configura-se como um elemento severamente explorado por Kafka em sua obra. O Estado se assemelha à figura de opressor, apto a tomar a liberdade e a paz do cidadão.

Tomando por comentários à obra de Kafka, Diocleciano Torrieri Guimarães, tradutor do título aqui estudado, o temor é realmente um dos elementos mais atuantes na dinâmica do presente livro, "como decorrência do assombro que provoca no homem a sua debilidade em confronto com a vitalidade impressionante dos problemas que permanentemente o assoberbam" (KAFKA, 2011, p.35-36). Por reflexão, toma parte em uma analogia do processo vivido pelo Sr. K, para com a existência de cada um dos homens na Terra. Para tal, o processo é a existência analisada por elementos estranhos ao mundo íntimo, análise que também força o homem a tentar desvendar-se aos próprios olhos. Conforme Torrieri Guimarães, o homem não governa o seu destino; enquanto ser isolado em seu mundo, uma vez que vivendo em sociedade, em permanente choque com a humanidade, é conduzido pelas forças do espírito e da matéria, que

\footnotetext{
${ }^{26}$ Tomando nota na contribuição do Direito na presente obra, o modo de ser e o caráter dos juristas, especialmente os advogados, no Processo apresentado como vilão, fornece brilhante oportunidade para o estudo da ética profissional. (SCHWARTZ; MACEDO, 2006).
} 
juntamente com as corrupções ${ }^{27}$ do ambiente o guiam à morte, momento ao qual tal como uma instância superior, o homem apresentar-se-ia ao Juiz incorruptível e eterno que o julgaria ao final. A sociedade do século XX, portanto, expressada em duras linhas a partir de Franz Kafka, mostrava-se desse modo sujeita à frieza das disposições procedimentais, tal como maquinários em um complexo fabril.

\section{5) Considerações conclusivas: Dos pontos de intersecção}

Das três clássicas obras supra analisadas, ainda que em rápida passagem e síntese, pôde-se destacar desde já que ambas apresentam em seu teor, crítica ao Direito. Já se explicou no tópico oportuno quais eram as especificidades de cada obra no tocante ao panorama jurídico, todavia, resta agora de ingente interesse abordá-los conjuntamente. Tanto no período que remonta à clássica Grécia Antiga, como na Veneza renascentista e na complexa cidade do século XX, fez-se menção a discussões que tinham por finalidade a exaração de uma sentença. Para tanto, naturalmente, para alcançar tal decisão, um procedimento específico deveria ser enfrentado e vivido apaixonadamente pelos personagens, momento então que os autores dedicavam maior tempo e carga emocional, não só para prender a atenção do leitor, mas também para deixar a obra convidativa, atraente e igualmente perturbadora. De igual maneira, a forma como os personagens reagiam aos confrontos forenses, sempre muito bem fundamentados em suas convicções, traziam à tona aspectos sociais, religiosos e psicológicos que nunca pareciam coincidir com o ponto de vista do magistrado e do arcabouço que justificara tal processo. Antígona, desejosa de garantir uma cerimônia fúnebre ao seu amado irmão em contraste com o decreto imperial. Shylock, munido de suas aspirações e resguardado por um contrato e um sentimento de vingança que ultrapassava sua pessoa e por fim, o Sr. K, inserto em um ambiente totalmente hostil, que lhe tomava o fôlego, parte prejudicada de um burocrático sistema forense, ao alcance da complexidade do Séc XX. O ideal de justo, nesse sentido, conforme os recortes históricos marcados na literatura estudada, era abalizado sob pontos distintos, sendo guiado a partir do costume local, muitas vezes contrastando-se com o direito posto, nem sempre sob seu amparo.

\footnotetext{
${ }^{27}$ Em comento à obra de Kafka, Torrieri Guimarães, tomando as complexidades da vida humana ao passo da certeza da morte, salienta que "o mundo exterior parece contaminado sempre, ainda nos seus aspectos mais puros. [...] Tudo isso é chocante para um espírito que deseja manter-se íntegro; o mais leve deslize, [...] parece-lhe uma recaída na falta original. O complexo da culpa cria problemas insolúveis; já nascemos culpados, e durante toda a vida apenas agravamos os nossos pecados. O processo a que estamos submetidos em nossa existência terrena é muito justo e se nós o aceitamos sem recalcitrância podemos, talvez, atrair sobre nós a indulgência do Supremo Juiz" (KAFKA, 2011, p.35).
} 
Curiosamente, os três personagens principais sucumbiram diante da estrutura jurídica que pesava sobre seus ombros, trazendo à baila a derrocada de suas convicções, com a conseguinte vitória do sistema opressor. Certamente, não existem dúvidas de que as três obras supra estudadas, como nenhuma outra, retratam com vigor a estrutura jurídica nos períodos históricos ao qual as obras são narradas. Não por outra razão, consistem em importante fonte de estudo para aquele que deseja se aprofundar na historicidade do Direito. Detém a completa razão Schwartz quando remonta que o estudo do Direito na Literatura é de fato aquele que "se apresenta como o mais construído e desenvolvido, pois, aqui, o acoplamento entre o sistema jurídico e o sistema da arte é latente, visto que existem imbricações bastante óbvias possibilitadas pela comunicação entre os textos" (SCHWARTZ; MACEDO, 2006, p.1024). Pelos olhos da arte, conseguem os estudiosos alcançar especificidades e detalhes dos modelos jurídicos que investigações técnicas jamais seriam capazes de alcançar. Não por outra razão, valoriza-se a conexão entre tais perspectivas, intento ao qual procurou o presente texto, ainda que em brevíssimas anotações, considerar.

Ademais, não bastassem as ricas impressões jurídicas perpassadas a partir do ambiente vivido pelos personagens, ainda que assim não fosse, tais manifestações artísticas contemplam sobretudo, valiosas sensações que conseguem imprimir, a sensação de prazer e encantamento aquele que nelas se debruçar. Não por outra razão, tais obras apresentam o Direito no estado da Arte.

\section{6) Referências}

ALVES, Marcelo. Antígona e o Direito. Curitiba: Juara Editora, 2007. Disponível em: <https://www.jurua.com.br/bv/conteudo.asp?id=20472\#proxima> Acesso em: 03 jan 2016.
ABBAGNANO, Nicola. Dicionário de Filosofia. Tradução Alfredo Bosi, $6^{\circ}$ Ed. São Paulo: Editora WMF Martins Fontes, 2012.

BARROS, Gilda Naécia Maciel de. Antígona - o crime santo, a piedade ímpia. s/a. Disponível em: 〈http://hottopos.com/videtur25/gilda.htm> Acesso em: 02 jan 2016.

BRANDÃO, Cláudio. O Direito Grego Clássico. História do direito e do pensamento jurídico em perspectiva. Coord. Cláudio Brandão. São Paulo: ed. Atlas, 2012.

CARNELUTTI, Francesco. A Arte do Direito: seis meditações sobre o direito. $2^{\mathrm{a}}$ ed. Campinas: Bookseller, 2005.

COUlAngES, Fustel de. A Cidade Antiga. $1^{a}$ edição, Trad. Heloisa da Graça Burati, Biblioteca Clássica, São Paulo: Rideel, 2005. 
FERRAZ JÚNIOR, Tercio Sampaio. Introdução ao Estudo do Direito, Técnica, Decisão, Dominação. $6^{\circ}$ edição, São Paulo: ed. Atlas, 2009.

KAFKA. Franz. O processo. Tradução Torrieri Guimarães. $-5^{\circ}$ ed. São Paulo: Martin Claret, 2011.

JAEGER, Werner. Alabanza de la ley: Los origenes de la filosofia del derecho y los griegos, Centro de Estudios Constitucionales, Madrid, 1982. Disponível em: https://dialnet.unirioja.es/descarga/.../2129409.pdf Acesso em: 20 jan 2016.

NIETZSCHE, Friedrich. A origem da tragédia proveniente do espírito da música. Trad. Erwin Theodor, Ed. Cupolo. 1948/ eBooksBrasil. 2006.

SHAKESPEARE, William. O Mercador de Veneza. Trad. Helena Barbas, Almada: Água Forte, 2002.

SCHWARTZ, Germano; MACEDO, Elaine. Pode o Direito ser Arte? Respostas a partir do Direito e Literatura. XV Congresso Nacional de Pesquisa e Pós-Graduação em Direito CONPEDI, Manaus, 2006.

SILVA, Cristian Kiefer da; RIBEIRO, Fernando José Armando. Shakespeare e a Lei: Conciliação e pacificação em "Romeo and Juliet". XXIII Congresso Nacional de Pesquisa e Pós-Graduação em Direito - CONPEDI, João Pessoa, 2014.

SÓFOCLES. Antígone. Trad. J.B. de Melo e Souza, e-books Brasil, 2005. Disponível em: <www.ebooksbrasil.org/adobeebook/antigone.pdf> Acesso em: 30 out 2015. 